\title{
Sternal Index in Human Fetuses as an Indicator of Sexual Dimorphism
}

\author{
José Aderval Aragão, ${ }^{1}$ Higor Dantas Gonçalves Carvalho ${ }^{2}$ Ícaro Quintela Matos, ${ }^{2}$ Renan Santos Cavalcanti, ${ }^{2}$ lapunira \\ Catarina Sant'Anna Aragão, ${ }^{3}$ Felipe Matheus Sant'Anna Aragão, ${ }^{3}$ Pedro Henrique Adário Marassi, ${ }^{3}$ Paôla Cardoso, ${ }^{3}$ \\ Bárbara Costa Lourenço, ${ }^{4}$ Francisco Prado Reis, ${ }^{5}$
}

\author{
${ }^{1}$ Associate Professor of Clinical Anatomy, Department of Morphology, Federal University of Sergipe (UFS), Aracaju, SE, Brazil \\ ${ }^{2}$ Medical Student at the Federal University of Sergipe (UFS), Aracaju, SE, Brazil \\ ${ }^{3}$ Medical Student, University Center of Volta Redonda (UNIFOA), Volta Redonda, RJ, Brazil \\ ${ }^{4}$ Medical Student, Três Rios Faculty of Medical Sciences (FCM-TR), Três Rios, RJ, Brazil \\ ${ }^{5}$ Titular Professor, Medical School of Tiradentes University (UNIT), Aracaju, SE, Brazil
}

Disclose and conflicts of interest: none to be declared by all authors

\begin{abstract}
Introduction: the sternum bone is useful in morphological sex discrimination, especially when other bones with greater discrimination capacity are not available, such as the pelvis and some long bones. Results found in different population investigations, as well as the need to have reference values for the sternal index, have led to a significant increase in studies and publications in this regard.

Objective: in the present study, we analyzed the usefulness of the sternal index in human fetuses as an indicator of sexual dimorphism in a sample of 30 sternums, 15 males and 15 females.

Methods and Methods: all metric variables (lengths of the manubrium of the sternum and body of the sternum) were performed using a $0.01 \mathrm{~mm}$ precision digital caliper and the mean differences were statistically evaluated using the T Test and the MannWhitney Test.

Results: in general, the mean age of fetuses was 27.64 weeks. The length of the manubrium of the sternum bone was slightly greater in males, while the length of the body was similar in both genders. The sternal index was higher in males. According to the statistical analysis none of the three variables proved to be a good parameter as indicators of sexual dimorphism $(p>0.05)$. Conclusion: we conclude that the sternal index in human fetuses, despite being higher in males, was not effective as an indicator of sexual dimorphism. Finally, given the relatively small size of the study sample, it is recommended that further investigations be conducted in other samples of the Brazilian population to confirm the results of the present research. Keywords: Sex Determination by Skeleton; Sternum; Forensic anthropometry; Biometric Identification; Sternal index.
\end{abstract}

\section{Introduction}

Forensic medicine is a science of great importance and which, currently, is gaining even more relevance with the increase in the number of accidents, tragedies and various crimes. Within its performance, it has contributed to the knowledge of the correlation of bodily structures with height, age, sex and ethnicity, for human identification, especially in cases of mass disasters, armed conflicts, terrorist massacres, car or air accidents. ${ }^{1}$ The bone skeleton is the only structure that resists the effects of putrefaction and decomposition for a long time. ${ }^{2}$ Alongside the pelvis, the human skull is considered the most accurate bone indicator in sexual dimorphism. ${ }^{3}$ However, when these bones are not present, forensic anthropologists and bioarcheologists become dependent on other human elements with less sexual dimorphism, such as the sternum. ${ }^{1}$ Thus, the sternum has become an important bone structure of study for forensic anthropology in determining age, sex and other characteristics.

Morphometric variations specifically studied in the sternum have been observed, with emphasis on the conclusion that in males the bone has greater length when compared to females. ${ }^{4-6}$

Studies of linear measurements of the sternum, such as lengths of the manubrium, body and xiphoid process, showed a correlation between these measurements and gender. ${ }^{3,7}$ Gautam et al. ${ }^{9}$ reported an average length of the manubrium of $53 \mathrm{~mm}$ for males and $48 \mathrm{~mm}$ for females, while the average length of the combination of the manubrium and the body of the sternum was $149 \mathrm{~mm}$ and $124 \mathrm{~mm}$ for males and females, respectively. Changani et al. ${ }^{10}$ concluded that the combination of sternum and manubrium lengths is the most accurate criterion for sex determination.

Although morphometric measurements of the sternum are accurate for sex determination when analyzed alone or in combination, the sternal index has not been as effective and accurate in sex differentiation..$^{1,10}$ Changani et al. ${ }^{10}$ analyzed the population of Gujarat, India and found higher sternal indices in females, however they did not report statistical significance between the sexes. Singh et al. ${ }^{1}$ in a similar study, found sternal width index values 
highly deviated from the mean values and concluded that this criterion had a low degree of reliability in determining sex in their study.

Hunnargi et al..$^{11}$ reported that in different regions and populations, however small, variations in bone indexes and morphometry occur. In Brazil, there is a need for studies on aspects of sex determination through the sternum. Thus, it is of great importance that studies targeting the Brazilian region and population on the subject are carried out. The present study aims to determine the sternal index as an indicator of sexual differentiation in human fetuses.

\section{Materials and Methods}

Thirty sternums from human fetuses were used, being 15 male and 15 female. The fetuses belong to the Anatomy Laboratory of the Morphology Department of the Federal University of Sergipe and were obtained in accordance with Law 8501 of November 30, 1992, which provides for the use of unclaimed cadavers for the purposes of studies or scientific research. All fetuses of both sexes, in good general condition, available in the laboratory were included, and fetuses with spinal abnormalities such as kyphosis, lordosis, scoliosis, as well as those with any macroscopic malformation abnormality in the anterior region of the chest were excluded. This study was approved by the Ethics and Research Committee of the Federal University of Sergipe, protocol number: CAAE: 53613116.1.0000.5546. After individualization of the sternum, the following measurements were taken: lengths of the sternum manubrium (from the jugular or suprasternal notch to the sternal manubrium junction) and the sternum body (from the sternal manubrium junction to the xiphosternal junction) (Figure 1). Measurements were

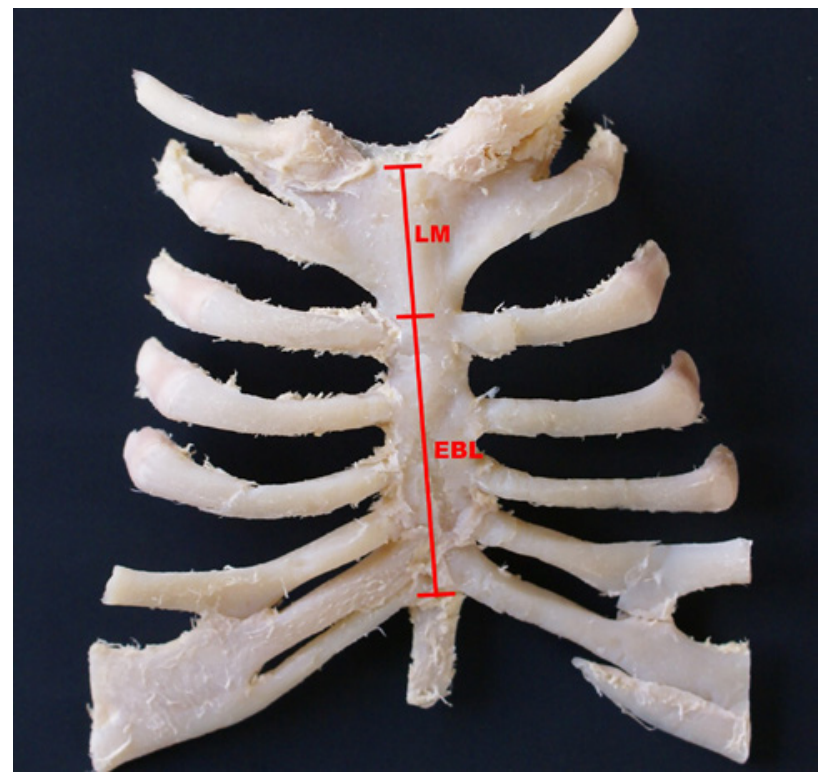

Figure 1. Morphometric measurements on the sternum.

LM - Length of the manubrium: distance between the jugular notch in the manubrium of the sternum to the manubrium sternal junction;

$\mathrm{EBL}$ - Sternum body length: distance between the sternal manubrium junction to the xiphosternal junction. performed using a $0.01 \mathrm{~mm}$ precision digital caliper. The sternal index was calculated by dividing the length of the manubrium by the body of the sternum, multiplied by 100. Data were described using mean, standard deviation, minimum and maximum. Mean differences were evaluated using T-Test and Mann-Whitney Test. The software used was the R Core Team 2018 and the significance level adopted was $5 \%$.

\section{Results}

The average age among the 30 fetuses was 27.64 weeks. In male fetuses, this variation was from 20.9 to 36.8 weeks, with an average of 28.12 weeks. For females, the variation was from 21.2 to 34.4 weeks and an average of 27.15 weeks. The analysis of the values of the measures of the lengths of the manubrium of the sternum and of the body of the sternum, as well as the sternal index (with mean, standard deviation, minimum and maximum values), showed that these measures were slightly higher in males than in females. According to the statistical analysis none of the three variables proved to be a good parameter as indicators of sexual dimorphism $(p>0,05)$ (Table 1$)$.

Table 1. Sternal morphometric values and their statistical analysis.

\begin{tabular}{|c|c|c|c|c|c|c|}
\hline & \multicolumn{2}{|c|}{$\begin{array}{c}\text { Female } \\
(n=15)\end{array}$} & \multicolumn{2}{|c|}{$\begin{array}{c}\text { Male } \\
(n=15)\end{array}$} & \multirow[b]{2}{*}{$\mathbf{T}$ (p-value) } & \multirow[b]{2}{*}{ p-value } \\
\hline & $\begin{array}{c}\text { Mean } \\
\text { (SD) }\end{array}$ & $\begin{array}{l}\text { Min } \\
\text { Max }\end{array}$ & $\begin{array}{c}\text { Mean } \\
\text { (SD) }\end{array}$ & $\begin{array}{l}\text { Min } \\
\text { Max }\end{array}$ & & \\
\hline $\begin{array}{l}\text { Length } \\
\text { of the } \\
\text { manubrium }\end{array}$ & $\begin{array}{c}12,4 \\
(2,84)\end{array}$ & $\begin{array}{l}8,98- \\
17,41\end{array}$ & $\begin{array}{c}13,33 \\
(3,06)\end{array}$ & $\begin{array}{l}8,83- \\
18,54\end{array}$ & $\begin{array}{c}0,86 \\
(0,396)\end{array}$ & 0,419 \\
\hline $\begin{array}{l}\text { Sternum } \\
\text { body } \\
\text { length }\end{array}$ & $\begin{array}{c}27,7 \\
(4,32)\end{array}$ & $\begin{array}{c}18,58- \\
33,82\end{array}$ & $\begin{array}{c}27,27 \\
(5,63)\end{array}$ & $\begin{array}{c}19,09- \\
36,51\end{array}$ & $\begin{array}{c}0,23 \\
(0,818)\end{array}$ & 0,820 \\
\hline $\begin{array}{l}\text { Sternal } \\
\text { index }\end{array}$ & $\begin{array}{c}45,51 \\
(10,61)\end{array}$ & $\begin{array}{c}27,58- \\
64,4\end{array}$ & $\begin{array}{l}49,03 \\
(6,22)\end{array}$ & $\begin{array}{c}39,16- \\
61,24\end{array}$ & $\begin{array}{c}1,11 \\
(0,277)\end{array}$ & 0,419 \\
\hline
\end{tabular}

T Test; Mann-Whitney Test; SD - Standard deviation.

\section{Discussion}

The sexual dimorphism of the human sternum with respect to its morphology and morphometry remains an important issue of discussion among forensic anthropologists. In the present study, the mean fetal sternal index found in males $(49.03 \mathrm{~mm})$ and females $(45.51 \mathrm{~mm})$ were lower when compared to other studies ${ }^{4,11-16}$ (Table 2). Perhaps these sternal index differences are related to population differences, age and race, in addition, all comparisons of values were performed based on adult sternums, while our work was performed on Brazilian human fetuses.

There is great disagreement in the literature about the effectiveness of the sternal index in determining sex. Singh et al. ${ }^{1}$ studied the sternum of the population of northeastern India, but although measurements of sternum body length and sternum manubrium were 
accepted as good indicators of dimorphism, they concluded that the sternal index did not prove to be a good indicator of sex, which is in accordance with our study. Changani et al. ${ }^{10}$ analyzing the population of Gujarat, India, found higher sternal indices in females and concluded that this index is also not accurate in sexual differentiation, corroborating our findings. Hunnargi et al. ${ }^{11}$ studied 115 sternums from West Indian and, unlike our study, found statistically significant values, and admitted that the sternal index is an excellent criterion to determine sex.

\section{Conclusion}

The morphometric measurements of body length, sternum manubrium and sternal index were not effective for the study of sexual dimorphism. Statistical analysis showed that the sternal index is not an indicator of sexual dimorphism ( $p>0.05)$. We propose that further studies with larger samples of human fetuses can be carried out, so that the sternal index can be used to determine the race and age of different populations.

Table 2. Comparison of the sternal index with other studies.

\begin{tabular}{|c|c|c|c|c|c|}
\hline Study & Sex & Bones (n) & Variation & Mean & Standard deviation \\
\hline Narayan \& Varm, & $\begin{array}{c}\text { Male } \\
\text { Female }\end{array}$ & $\begin{array}{c}126 \\
27\end{array}$ & $\begin{array}{c}31.72-85.33 \\
44.33-80.00\end{array}$ & $\begin{array}{l}54.76 \\
58.98\end{array}$ & $\begin{array}{l} \pm 9.94 \\
\pm 9.61\end{array}$ \\
\hline Jit et al. ${ }^{4}$ & $\begin{array}{c}\text { Male } \\
\text { Female }\end{array}$ & $\begin{array}{c}312 \\
88\end{array}$ & $\begin{array}{l}35.00-94.00 \\
32.00-88.00\end{array}$ & $\begin{array}{l}55.53 \\
61.80\end{array}$ & $\begin{array}{c} \pm 9.57 \\
\pm 10.62\end{array}$ \\
\hline Dahiphale et al..$^{13}$ & $\begin{array}{c}\text { Male } \\
\text { Female }\end{array}$ & $\begin{array}{l}96 \\
47\end{array}$ & $\begin{array}{l}36.00-77.00 \\
51.00-91.00\end{array}$ & $\begin{array}{l}51.99 \\
63.01\end{array}$ & $\begin{array}{l} \pm 8.34 \\
\pm 8.50\end{array}$ \\
\hline Atal at el. ${ }^{14}$ & $\begin{array}{c}\text { Male } \\
\text { Female }\end{array}$ & $\begin{array}{l}56 \\
44\end{array}$ & $\begin{array}{l}38.00-58.00 \\
45.00-62.00\end{array}$ & $\begin{array}{l}46.08 \\
56.70\end{array}$ & $\begin{array}{l}3.75 \\
3.98\end{array}$ \\
\hline Hunnargi et al.11 & $\begin{array}{c}\text { Male } \\
\text { Female }\end{array}$ & $\begin{array}{l}75 \\
40\end{array}$ & $\begin{array}{r}36.10-93.10 \\
36.30-88.10\end{array}$ & $\begin{array}{l}59.21 \\
63.31\end{array}$ & $\begin{array}{l}9.85 \\
9.41\end{array}$ \\
\hline Toneva \& Nikolova, ${ }^{15}$ & $\begin{array}{c}\text { Male } \\
\text { Female }\end{array}$ & $\begin{array}{l}47 \\
29\end{array}$ & $\begin{array}{c}34.50-68.50 \\
44.00-67.10\end{array}$ & $\begin{array}{l}50.40 \\
54.00\end{array}$ & $\begin{array}{l}6.80 \\
5.30\end{array}$ \\
\hline Dorado-Fernández et al. ${ }^{16}$ & $\begin{array}{c}\text { Male } \\
\text { Female }\end{array}$ & $\begin{array}{l}90 \\
64 \\
\end{array}$ & $\begin{array}{l}34.07-78.57 \\
38.88-78.12\end{array}$ & $\begin{array}{l}50.15 \\
54.91\end{array}$ & $\begin{array}{l}7.46 \\
8.12\end{array}$ \\
\hline Present Study & $\begin{array}{c}\text { Male } \\
\text { Female }\end{array}$ & $\begin{array}{l}15 \\
15\end{array}$ & $\begin{array}{l}39.16-61.24 \\
27.58-64.4\end{array}$ & $\begin{array}{l}49.03 \\
45.51\end{array}$ & $\begin{array}{c} \pm 6.22 \\
\pm 10.61\end{array}$ \\
\hline
\end{tabular}

\section{References}

1. Singh J, Pathak RK, Singh D. Morphometric sex determination from various sternal widths of Northwest Indian sternums collected from autopsy cadavers: A comparison of sexing methods. Egypt J Forensic Sci. 2012 Mar;2(1):18-28.

2. Puttabanthi S, Velichety SD, Padi T, Boddeti RK, Priyanka JR. Sexing of unknown adult human sterna by metrical analysis. Int J Biol Med Res. 2012;3(2): 1516-1519.

3. Macaluso PJ, Lucena, J. Estimation of sex from sternal dimensions derived from chest plate radiographs in contemporary Spaniards. Int J Legal Med. 2014 Mar; 128(2):389-95.

4. Jit I, Jhingan V, Kulkarni M. Sexing the human sternum. Am J Phys Anthropol. 1980 Aug;53(2):217-24.

5. Dwight T. The sternum as an index of sex and age. J Anat Physiol. 1881 Apr;15(Pt 3):327-330.

6. Hatfield MK, Gross BH, Glazer GM, Martel W. Computed tomography of the sternum and its articulations. Skeletal Radiol. 1984;11(3):197-203.

7. Teige K. Morphometric studies of X-rays of the sternum. Z Rechtsmed. J Legal Med; 1983;90(3):199-204.

8. Osunwoke EA, Gwunireama IU, Orish CN, Ordu KS, Ebowe I. A study of sexual dimorphism of the human sternum in the southern Nigerian population. J Appl Biosci. 2010 Jan;26:1636-9.

9. Gautam RS, Shah GV, Jadav HR, Gohil BJ. The human sternum: as an index of age and sex. J Anat Soc Ind. 2003;52(1):20-3.

10. Changani MV, Javia MD, Varma, KA. Determination of sex from various measurements of human sternum \& manubrium in Gujarat population. J Red Med Den Sci. 2014;2(1):59-65.

11. Hunnargi SA, Menezes RG, Kanchan T, Lobo SW, Uysal S, Herekar NG, Krishan K, Garg RK. Sternal index: Is it a reliable indicator of sex in the Maharashtrian population of India? J Forensic Leg Med. 2009 Feb;16(2):56-8.

12. Narayan D, Varma H C. Sternal index in UP males and females. J Anat Soc India 1958;7:71-2.

13. Dahiphale VP, Baheete BH, Kamkhedkar SG. Sexing the human sternum in Marathwada region. J Anat Soc India 2002;51:162-7.

14. Atal DK, Murari A, Naik SK. Role of Sternal Index in Determination of Gender. Indian Journal of Forensic Medicine and Pathology. 2008 July-Decmber; 1(3\&4): 71-74.

15. Toneva DH, Nikolova SI. Reliability of the Sternal Index as a sex indicator in medieval skeletal remains from Northeastern Bulgaria. J. BioSci. Biotech. 2014 May; Special Edition/Online:149-152.

16. Dorado-Fernández E, Cáceres-Monllor DA, Carrillo-Rodríguez MF, Botella-López M, Murillo-González J. The sternum as a sex discriminator in a contemporary spanish population. Rom J Leg Med. 2021 Mar;29(1):96-104. 


\section{Mini Curriculum and Author's Contribution}

1. José Aderval Aragão - MD; PhD. Contribution: Conception, Design, Supervision, Writing, Critical Review and final approval. ORCID: https://orcid.org/0000-0002-2300-3330

2. Higor Dantas Gonçalves Carvalho - Medical Student. Contribution: Data Collection and/or Processing, Analysis and/ or Interpretation, Critical Review and final approval. ORCID: https://orcid.org/0000-0003-1383-201X

3. Ícaro Quintela Matos - Medical Student. Contribution: Data Collection and/or Processing, Analysis and/or Interpretation, Critical Review and final approval. ORCID: https://orcid.org/0000-0001-7285-728X

4. Renan Santos Cavalcanti - Medical Student. Contribution: Data Collection and/or Processing, Analysis and/or Interpretation, Critical Review and final approval. ORCID: https://orcid.org/0000-0002-8729-7067

5. Iapunira Catarina Sant'Anna Aragão - Medical Student. Contribution: Data Collection and/or Processing, Analysis and/or Interpretation, Critical Review and final approval. ORCID: https://orcid.org/0000-0002-5298-537X

6. Felipe Matheus Sant'Anna Aragão - Medical Student. Contribution: Data Collection and/or Processing, Analysis and/ or Interpretation, Critical Review and final approval. ORCID: https://orcid.org/0000-0001-9211-7000

7. Pedro Henrique Adário Marassi - Medical Student. Contribution: Fundings, Materials, Data Collection and/or Processing, Literature Review and final approval. ORCID: https://orcid.org/0000-0001-6405-5068

8. Paôla Cardoso - Medical Student. Contribution: Fundings, Materials, Data Collection and/or Processing, Literature Review and final approval. ORCID: https://orcid.org/0000-0001-8722-9104

9. Bárbara Costa Lourenço - Medical Student. Contribution: Fundings, Materials, Data Collection and/or Processing, Literature Review and final approval. ORCID: https://orcid.org/0000-0001-5924-8658

10. Francisco Prado Reis - MD; PhD. Contribution: Conception, Design, Supervision, Writing, Critical Review and final approval. ORCID: https://orcid.org/0000-0002-7776-1831

Received: July 9, 2021

Accepted: September 28, 2021
Corresponding author

José Aderval Aragão

E-mail: adervalufs@gmail.com 